\title{
EFEKTIVITAS VAKSIN BIVALEN Aeromonas hydrophila DAN Mycobacterium fortuitum UNTUK PENCEGAHAN INFEKSI PENYAKIT PADA IKAN GURAMI (Osphronemus goramy)
}

\author{
Desy Sugiani", Yani Aryati, Tatik Mufidah, dan Uni Purwaningsih \\ Balai Penelitian dan Pengembangan Budidaya Air Tawar \\ (Naskah diterima: 18 Mei 2014; Revisi final: 11 Oktober 2015; Disetujui publikasi: 9 November 2015)
}

\begin{abstract}
ABSTRAK
Vaksinasi merupakan salah satu cara terbaik untuk pencegahan terhadap penyakit ikan. Aplikasi pemberian vaksin untuk skala massal oleh pembudidaya ikan masih menjadi kendala. Tujuan dari penelitian ini adalah untuk menguji efektivitas dan respons peningkatan kekebalan tubuh ikan terhadap penggunaan vaksin bivalen anti $A$. hydrophila dan M. fortuitum pada penanggulangan kejadian ko-infeksi $A$. hydrophila dan $M$. fortuitum pada ikan gurami. Perlakuan vaksinasi pada ikan gurami dilakukan selama empat minggu pemeliharan menggunakan tiga metode yang berbeda yaitu melalui injeksi, perendaman, dan oral, setiap perlakuan diulang sebanyak tiga kali dan diuji tantang selama empat minggu dengan ko-infeksi dari $A$. hydrophila dan $M$. fortuitum. Nilai RPS (relative percent survival) terbaik setelah uji tantang untuk penggunaan vaksin bivalen melalui perendaman pada benih ikan gurami adalah sebesar $26,4 \%$ lebih rendah dibandingkan dengan metode injeksi (56,33\%). Vaksin bivalen kurang efektif jika diberikan melalui oral dengan nilai RPS 13,6\%. Dosis vaksin bivalen terbaik untuk perlakuan vaksinasi melalui injeksi, perendaman, dan oral adalah campuran antara bakteri $A$. hydrophila $10^{10} \mathrm{cfu}$ dan $M$. fortuitum $10^{9} \mathrm{cfu}$ dengan perbandingan $1: 1 \mathrm{v} / \mathrm{v}$.
\end{abstract}

KATA KUNCI: vaksin bivalen, injeksi, perendaman, oral, RPS

ABSTRACT: $\quad$ Application of vaccines bivalent Aeromonas hydrophila and Mycobacterium fortuitum for infectious disease prevention in giant gouramy (Osphronemus goramy). By: Desy Sugiani, Yani Aryati, Tatik Mufidah, and Uni Purwaningsih

\begin{abstract}
Vaccination is one of the best ways for the prevention of fish diseases. Application of vaccines for mass scale by fish farmers still becomes an obstacle. The aim of this study was to examine the effectiveness and the optimal immune response of fish to the bivalent vaccine anti $A$. hydrophila and $M$. fortuitum used to control the incidence of coinfection of A. hydrophila and $M$. fortuitum in giant gouramy. Treatment of vaccination in giant gouramy was carried out for four weeks used three different methods, by injection, immersion, and oral, where each treatment was repeated three times and tested during the four weeks challenge with the co-infection of A. hydrophila and M. fortuitum. The best RPS value after challenge test for the application of the bivalent vaccine in giant gouramy was obtained by injection method (56.33\%) higher than the immersion (26.4\%). Bivalent vaccine were less effective when given orally was only obtained $13.6 \%$ RPS. The optimum doses of bivalent vaccine for treatment of vaccination by injection, immersion, and oral were a mixture of bacteria A. hydrophila $10^{10} \mathrm{cfu}$ and M. fortuitum $10^{9} \mathrm{cfu}$ with a ratio of 1:1 $v / v$.
\end{abstract}

KEYWORDS: $\quad$ bivalent vaccine, injection, immersion, oral, RPS

\section{PENDAHULUAN}

Vaksinasi ikan untuk melawan berbagai infeksi bakteri patogen secara serempak dapat dilakukan dengan menggunakan vaksin bivalen (vaksin yang mengandung dua jenis patogen) atau polivalen (vaksin yang mengandung beberapa jenis patogen). Strategi

\# Korespondensi: Balai Penelitian dan Pengembangan Perikanan Budidaya Air Tawar. Jl. Raya Sempur No. 1, Bogor 16154, Indonesia. Tel.: + (0251) 8313200

E-mail: desysugiani@yahoo.co.id vaksinasi yang ideal perlu memenuhi beberapa kriteria berikut ini, penyakit spesifik yang akan dipapar, jenis vaksin, metode vaksinasi, pemilihan waktu vaksinasi, dan perlakuan vaksinasi ulang (booster). Vaksin polivalen harus mampu melindungi dari semua serotipe dari tiap patogen penyebab penyakit tertentu. Namun, kemungkinan adanya kompetisi antigen spesifik yang mungkin terjadi terutama ketika vaksin diaplikasikan melalui injeksi perlu diperhatikan (Toranzo et al., 2009). 
Teknologi vaksinasi masih sangat dibatasi oleh pengetahuan mengenai sistem respons imun ikan atau inang terhadap penyakit tersebut. Kandidat vaksin terbaik dapat diujikan secara langsung pada ikan dengan menghitung jumlah ikan yang mati dan hidup (Sommerset et al., 2005).

Terdapat batasan usia minimal untuk melakukan vaksinasi, yaitu pada saat imunokompeten (beberapa waktu setelah kantung kuning telur habis diserap). Pemberian vaksin juga dibatasi oleh ukuran ikan, karena hanya ukuran besar yang mungkin dilakukan vaksinasi melalui injeksi, untuk penggunaan pada benih ikan yang ukuran lebih kecil biasanya diberikan dengan metode perendaman atau melalui oral (dicampur dengan pakan) (Evensen, 2009; Osman et al., 2009; Suanyuk \& Itsaro, 2011). Ketiga cara ini memiliki keuntungan dan kerugian yang akan memengaruhi level proteksi, efek samping yang ditimbulkan, cara pemberian, dan jumlah biaya yang diperlukan untuk kegiatan vaksinasi. Pemberian vaksinasi melalui injeksi telah banyak digunakan dalam skala riset di laboratorium hingga skala industri dengan hasil yang baik dengan alur mekanisme pembentukan respons imunitas juga telah diketahui, akan tetapi pemberian vaksin melalui oral dan perendaman masih belum banyak diketahui alur penyerapan antigen dan presentasi antigen setelah diserap (Gudmundsdottir et al., 2009). Sehingga, tujuan dari penelitian ini adalah untuk menguji efektivitas dan respons peningkatan kekebalan tubuh ikan terhadap penggunaan vaksin bivalen anti $A$. hydrophila dan $M$. fortuitum untuk menanggulangi kejadian ko-infeksi $A$. hydrophila dan M. fortuitum pada ikan gurami.

\section{BAHAN DAN METODE}

\section{Ikan Uji}

Ikan gurami (0. goramy) berukuran $25 \pm 2$ g/ekor berasal dari daerah Parung, Bogor. Aklimatisasi ikan uji dilakukan selama 28 hari untuk mengantisipasi munculnya gejala klinis infeksi $M$. fortutitum dan $A$. hydrophila. Sampel ikan diambil untuk konfirmasi bahwa ikan uji tersebut adalah bebas dari infeksi $M$. fortutitum dan A. hydrophila. Isolasi bakteri dilakukan secara individual terhadap organ ginjal, otak, dan mata, selanjutnya dikarakterisasi secara biokimia menggunakan API System.

\section{Pakan ikan}

Selama pemeliharaan ikan digunakan pakan komersial dengan kandungan protein $33 \%$, sedangkan pakan diberikan dengan jumlah $2 \%-3 \%$ /hari dari berat biomassa ikan.

\section{Vaksin Bakterin Inaktif}

Vaksin sel utuh $A$. hydrophila dibuat dengan metode tanam kering di media TSA, menggunakan isolat koleksi BPPBAT Bogor dengan kode A. hydrophila AHL0905. Vaksin sel utuh $M$. fortuitum dibuat dengan metode tanam kering di media Shouten agar, menggunakan isolat koleksi BPPBAT Bogor dengan kode M. fortuitum 31. Bakteri diinokulasi dalam media agar (TSA untuk $A$. hydrophila dan Shouten agar untuk M. fortuitum), inokulan ditanam secara merata di seluruh permukaan media agar, kemudian diinkubasi dalam inkubator $(A$. hydrophila selama \pm 24 jam dan $M$. fortuitum selama \pm 72 jam, pada suhu $30^{\circ} \mathrm{C}$ ). Pemanenan bakteri dilakukan menggunakan ose, dipanen sampai semua koloni terambil, kemudian dimasukkan ke dalam saline water $(\mathrm{NaCl} 0,845 \%)$, hasil pemanenan ini digunakan sebagai larutan stok. Stok bakteri tersebut dihitung kepekatannya dengan metode platting untuk mendapatkan kepadatan koloni (cfu). Suspensi bakteri dalam saline water diinaktivasi dengan menambahkan NBF (neutral buffer formalin) 3\% (v/v). Khusus untuk vaksin bakterin $M$. fortuitum tahapan pembuatan vaksin dilanjutkan disonikator dengan power $150 \mathrm{~W}$ selama \pm 5 menit dalam kondisi on-ice (dingin) dengan interval satu menit dan diulang empat kali. Suspensi bakteri yang sudah inaktif disimpan pada suhu $4^{\circ} \mathrm{C}$. Tahapan terakhir, larutan stok dari bakterin in-aktif tersebut kemudian diencerkan menggunakan saline water untuk mendapatkan kepadatan koloni yang diinginkan.

\section{Vaksin Bivalen}

Vaksin bivalen dibuat menggunakan komposisi terbaik dengan mencampurkan masing-masing sediaan vaksin bakteri inaktif $A$. hydrophila $10^{11}$ cfu dan $M$. fortuitum $10^{10} \mathrm{cfu}$ dengan perbandingan 1:1 (v/v) (Sugiani et al., 2013; Purwaningsih et al., 2014).

\section{Perlakuan Vaksinasi}

Aklimatisasi hewan uji dilakukan selama 28 hari untuk mengantisipasi munculnya gejala klinis Micobacteriosis dan MAS. Penelitian dilakukan secara eksperimental di laboratorium dengan menggunakan tiga perlakuan vaksin bivalen dan satu kontrol, dengan tiga kali ulangan. Perlakuan pertama adalah vaksinasi melalui injeksi (intraperitoneal), perlakuan kedua adalah vaksinasi melalui perendaman, dan perlakuan ketiga adalah vaksinasi melalui oral (pakan). Masing-masing perlakuan menggunakan tiga dosis vaksin yang berbeda yaitu dosis pengenceran ke- 1 (A. hydrophila $10^{10} \mathrm{cfu}$ dan M. fortuitum $10^{9} \mathrm{cfu}$, rasio $\left.1: 1 \mathrm{v} / \mathrm{v}\right)$, dosis pengenceran ke-2 $(A$. hydrophila $10^{9} \mathrm{cfu}$ dan $M$. fortuitum $10^{8} \mathrm{cfu}$, rasio $1: 1 \mathrm{v} / \mathrm{v}$ ), dan dosis pengenceran ke-3 (A. hydrophila $10^{8}$ cfu dan M. fortuitum $10^{7} \mathrm{cfu}$, rasio $\left.1: 1 \mathrm{v} / \mathrm{v}\right)$. 
Ikan dipelihara selama 28 hari pascavaksinasi dan dilakukan uji tantang mono-infeksi dan ko-infeksi bakteri $A$. hydrophila dan $M$. fortuitum menggunakan dosis infeksi ko-infeksi $A$. hydrophila $10^{8}$ cfu dan $M$. fortuitum $10^{7}$ cfu (LD-50) hasil koch-postulat ke-2 kali. Uji tantang dilakukan melalui injeksi intraperitoneal 0,1 mL/ekor ikan, ikan dipelihara kembali selama 28 hari untuk melihat kematian dan gejala klinis yang muncul.

Protokol pelaksanaan vaksinasi harus diikuti dengan seksama. Penggunaan vaksinasi melalui oral (pakan) disesuaikan dengan ukuran ikan, penyimpanan vaksin harus pada suhu dingin $\left(2^{\circ} \mathrm{C}-8^{\circ} \mathrm{C}\right)$, ikan dipuasakan 48-72 jam sebelum vaksinasi, semua peralatan vaksinasi harus dalam keadaan steril (didesinfeksi), dilakukan penimbangan ikan dan merekam minimum-maksimum dan rata-rata bobot ikan untuk menghitung dosis vaksin apabila diberikan dengan dicampur pakan. Penggunaan vaksinasi melalui injeksi dilakukan secara intreperitoneal dengan panjang jarum yang digunakan 1-2 mm agar dapat penetrasi ke dalam rongga perut, setiap ikan disuntik pada 1-1,5 cm setelah anterior sampai ke pangkal sirip perut, metode vaksinasi harus diatur secara benar untuk meminimalkan penanganan stres pada ikan. Penggunaan vaksinasi melalui perendaman dilakukan pada media air 30 liter diisi dengan 80 ekor ikan (rata-rata bobot ikan $35,5 \pm 6 \mathrm{~g}$; dengan panjang rata-rata $12,7 \pm 3 \mathrm{~cm}$ ) direndam selama satu jam menggunakan volume vaksin dari dosis hasil injeksi terbaik yaitu campuran antara bakteri $A$. hydrophila $10^{11} \mathrm{cfu}$ dan $M$. fortutium $10^{10} \mathrm{cfu}$ proporsi $1: 1 \quad(50 \%: 50 \%, \mathrm{v} / \mathrm{v})$. Uji tantang dilakukan dengan tiga kali ulangan di mana setiap bak pemeliharaan dengan perlakuan vaksiansi diisi dengan 25 ekor ikan, sedangkan pada perlakuan kontrol diisi 20 ekor ikan. Jumlah ikan pada bak perlakuan vaksinasi lebih banyak karena pada kelompok ini diperlukan sampel darah ikan lebih banyak untuk beberapa parameter uji hematologi.

Pengumpulan data dilakukan dengan pencatatan secara langsung terhadap gejala klinis yang teramati dan kematian ikan. Gambaran hematologi untuk melihat respons imun ikan dilakukan setiap satu minggu selama masa pemeliharaan proses induksi vaksin dan setiap minggu selama pemeliharaan setelah uji tantang. Gejala klinis diamati dengan melihat tingkah laku makan, berenang, respons terhadap kejutan, dan perubahan morfologi bagian luar tubuh ikan maupun anatomi organ dalam ikan. Gambaran sistem imun dilakukan dengan mengamati sampel darah yang diambil dari ikan perlakuan kemudian diukur antibodi spesifik menggunakan metode direct aglutination. Relative percent survival (RPS) diamati untuk melihat efektivitas vaksinasi dengan menggunakan rumus Ellis (1988):

$$
\mathrm{RPS}=\left(1-\frac{\text { per cent vaccinate mortality }}{\text { per cent control mortality }}\right) \times 100
$$

\section{HASIL DAN BAHASAN}

Vaksin $A$. hydrophila dan $M$. fortuitum memiliki potensi untuk dibuat dalam bentuk bivalen (vaksin dengan kandungan dua antigen bakteri) (Sugiani et al., 2013). Pemberian vaksin harus memenuhi beberapa kaidah vaksinasi. Sebelum dilakukan vaksinasi kesehatan ikan harus terjamin dengan melihat pola perilaku ikan, nafsu makan, dan tingkat sintasan.

\section{Penggunaan Vaksin Bivalen A. hydrophila dan $M$. fortuitum Melalui Injeksi}

Vaksinasi melalui injeksi akan selalu membawa beberapa risiko, meskipun sangat kecil persentase ikan mati setelah perlakuan tersebut, tergantung pada kemampuan toleransi individu ikan terhadap stres dan keterampilan dari operator serta biosekuriti umum selama proses vaksinasi.

Hasil penelitian yang telah dihasilkan (Sugiani et al., 2013) menunjukkan bahwa vaksin bivalen campuran terbaik adalah antara bakteri $A$. hydrophila $10^{11} \mathrm{cfu}$ dan M. fortutium $10^{10} \mathrm{cfu}$ proporsi 1:1 (50\%:50\%, v/v) diperoleh rata-rata RPS sebesar $52 \%$ dengan perincian 46\% jika diuji tantang dengan A. hydrophila, 57\% jika diuji tantang dengan $M$. fortuitum, dan 53\% jika diuji tantang dengan ko-infeksi $A$. hydrophila dan $M$. fortuitum. Vaksin yang ideal harus terbuat dari sediaan vaksin dengan dosis yang tepat, untuk mendapatkan vaksin dengan efektivitas yang tinggi maka dilakukan pengenceran terhadap dosis sediaan vaksin yang sudah ada dan dilakukan juga uji pemberian vaksin untuk melihat efikasi melalui injeksi yaitu $50 \mathrm{AH}$ : $50 \mathrm{MF}$ pengenceran ke-1 (campuran antara bakteri $A$. hydrophila $10^{10} \mathrm{cfu}$ dan $M$. fortutium $10^{9} \mathrm{cfu}$ ), $50 \mathrm{AH}$ : $50 \mathrm{MF}$ pengenceran ke-2 (campuran antara bakteri $A$. hydrophila $10^{9} \mathrm{cfu}$ dan $M$. fortutium $10^{8} \mathrm{cfu}$ ), dan $50 \mathrm{AH}$ : $50 \mathrm{MF}$ pengenceran ke-3 (campuran antara bakteri A. hydrophila $10^{8} \mathrm{cfu}$ dan $M$. fortutium $10^{7} \mathrm{cfu}$ ).

Nilai rata-rata RPS berturut-turut dari perlakuan dosis terbaik melalui injeksi adalah sediaan vaksin $A$. hydrophila $10^{10}$ cfu dan $M$. fortuitum $10^{9} \mathrm{cfu}$, rasio $1: 1$ v/v (56,33\%); sediaan vaksin $A$. hydrophila $10^{9} \mathrm{cfu}$ dan M. fortuitum $10^{8} \mathrm{cfu}$, rasio $1: 1 \mathrm{v} / \mathrm{v}(20,67 \%)$, dan sediaan vaksin A. hydrophila $10^{8}$ cfu dan M. fortuitum $10^{7} \mathrm{cfu}$, rasio 1:1 v/v (19\%). Dari hasil tersebut diperoleh dosis vaksin yang paling efektif untuk vaksin bivalen $A$. hydrophila dan $M$. fortuitum yaitu vaksin campuran antara bakteri $A$. hydrophila $10^{10} \mathrm{cfu}$ dan $M$. fortutium $10^{9} \mathrm{cfu}$ dengan rasio $1: 1 \mathrm{v} / \mathrm{v}$ (Tabel 1 ). 
Tabel 1. Efikasi vaksinasi bivalen A. hydrophila dan M. fortuitum melalui injeksi Table 1. Efficacy of a bivalent vaccine A. hydrophila and M. fortuitum by injection

\begin{tabular}{|c|c|c|c|c|}
\hline $\begin{array}{l}\text { Perlakuan uji tantang } \\
\text { Challenge test }\end{array}$ & $\begin{array}{c}\text { RPS } \\
(\%)\end{array}$ & $\begin{array}{l}\sum \text { Ikan hidup } \\
\text { Survival fish }\end{array}$ & $\begin{array}{l}\text { ¿Ikan mati } \\
\text { Mortality }\end{array}$ & $\begin{array}{l}\text { Sintasan } \\
\text { Survival rate } \\
\quad(\%)\end{array}$ \\
\hline $\begin{array}{l}\text { AH } 10^{10} \mathrm{cfu} \text { dan MF } 10^{9} \mathrm{cfu} \text { rasio } 1: 1 \mathrm{v} / \mathrm{v} \text {, diuji tantang AH } \\
\text { AH } 10^{10} \mathrm{cfu} \text { and } M F 10^{9} \mathrm{cfu} \text { ratio } 1: 1 \mathrm{v} / \mathrm{v} \text {, challenged with } A H\end{array}$ & 50 & 10 & 5 & 66.67 \\
\hline $\begin{array}{l}\text { AH } 10^{10} \mathrm{cfu} \text { dan MF } 10^{9} \mathrm{cfu} \text { rasio } 1: 1 \mathrm{v} / \mathrm{v} \text {, diuji tantang MF } \\
\text { AH } 10^{10} \mathrm{cfu} \text { and } M F 10^{9} \mathrm{cfu} \text { ratio } 1: 1 \mathrm{v} / \mathrm{v} \text {, challenged with } M F\end{array}$ & 86 & 14 & 1 & 93.33 \\
\hline $\begin{array}{l}\text { AH } 10^{10} \mathrm{cfu} \text { dan MF } 10^{9} \mathrm{cfu} \text { rasio } 1: 1 \mathrm{v} / \mathrm{v} \text {, diuji tantang ko-infeksi } \\
\text { AH } 10^{10} \mathrm{cfu} \text { and MF } 10^{9} \mathrm{cfu} \text { ratio } 1: 1 \mathrm{v} / \mathrm{v} \text {, challenged with co-infection }\end{array}$ & 33 & 7 & 8 & 46.67 \\
\hline $\begin{array}{l}\text { AH } 10^{9} \text { cfu dan MF } 10^{8} \text { cfu rasio } 1: 1 \mathrm{v} / \mathrm{v} \text {, diuji tantang } \mathrm{AH} \\
\text { AH } 10^{9} \text { cfu and } M F 10^{8} \text { cfu ratio } 1: 1 \mathrm{v} / \mathrm{v} \text {, challenged with } A H\end{array}$ & 20 & 7 & 8 & 46.67 \\
\hline $\begin{array}{l}\text { AH } 10^{9} \text { cfu dan MF } 10^{8} \text { cfu rasio } 1: 1 \mathrm{v} / \mathrm{v} \text {, diuji tantang MF } \\
\text { AH } 10^{9} \text { cfu and } M F 10^{8} \text { cfu ratio } 1: 1 \mathrm{v} / \mathrm{v} \text {, challenged with } M F\end{array}$ & 42 & 11 & 4 & 73.33 \\
\hline $\begin{array}{l}\text { AH } 10^{9} \text { cfu dan MF } 10^{8} \text { cfu rasio } 1: 1 \mathrm{v} / \mathrm{v} \text {, diuji tantang ko-infeksi } \\
\text { AH } 10^{9} \mathrm{cfu} \text { and MF } 10^{8} \mathrm{cfu} \text { ratio } 1: 1 \mathrm{v} / \mathrm{v} \text {, challenged with co-infection }\end{array}$ & 0 & 0 & 15 & 0 \\
\hline $\begin{array}{l}\text { AH } 10^{8} \mathrm{cfu} \text { dan MF } 10^{7} \mathrm{cfu} \text { rasio } 1: 1 \mathrm{v} / \mathrm{v} \text {, diuji tantang } \mathrm{AH} \\
\text { AH } 10^{8} \mathrm{cfu} \text { and } M F 10^{7} \mathrm{cfu} \text { ratio } 1: 1 \mathrm{v}, \mathrm{v} \text {, challenged with } A H\end{array}$ & 0 & 4 & 11 & 26.67 \\
\hline $\begin{array}{l}\text { AH } 10^{8} \mathrm{cfu} \text { dan MF } 10^{7} \mathrm{cfu} \text { rasio } 1: 1 \mathrm{v} / \mathrm{v} \text {, diuji tantang MF } \\
\text { AH } 10^{8} \mathrm{cfu} \text { and MF } 10^{7} \mathrm{cfu} \text { ratio } 1: 1 \mathrm{v} / \mathrm{v} \text {, challenged with } M F\end{array}$ & 57 & 12 & 3 & 80 \\
\hline $\begin{array}{l}\text { AH } 10^{8} \text { cfu dan MF } 10^{7} \text { cfu rasio } 1: 1 \mathrm{v} / \mathrm{v} \text {, diuji tantang ko-infeksi } \\
\text { AH } 10^{8} \text { cfu and MF } 10^{7} \text { cfu ratio } 1: 1 \mathrm{v} / \mathrm{v} \text {, challenged with co-infection }\end{array}$ & 0 & 0 & 15 & 0 \\
\hline $\begin{array}{l}\text { Kontrol diuji tantang } \mathrm{AH} \\
\text { Controls challenged with } \mathrm{AH}\end{array}$ & & 5 & 10 & 33.33 \\
\hline $\begin{array}{l}\text { Kontrol diuji tantang MF } \\
\text { Controls challenged with MF }\end{array}$ & & 8 & 7 & 53.33 \\
\hline $\begin{array}{l}\text { Kontrol diuji tantang ko-infeksi } \\
\text { Controls challenged with co-infection }\end{array}$ & & 3 & 12 & 20 \\
\hline
\end{tabular}

Keterangan: AH: Aeromonas hydrophila, MF : Mycobacterium fortuitum

Remark: AH: Aeromonas hydrophila, MF: Mycobacterium fortuitum

Hasil analisis beberapa data hematologi pada ikan gurami setelah vaksinasi dan uji tantang dengan bakteri homolog maupun heterolog menunjukkan adanya perubahan dalam titer antibodi. Pemberian vaksin bivalen dapat memengaruhi respons imun, diduga dengan adanya antibodi akan menginisiasi aksi berantai komplemen sehingga lisozim serum dapat masuk ke dalam lapisan peptidoglikan bakteri dan menyebabkan kematian sel. Aktivasi komplemen melalui penggabungan dengan antibodi dan bakteri juga menghasilkan anfilaktoksin C3a dan C5a yang berujung pada transudasi luas dari komponen serum, termasuk antibodi yang lebih banyak, dan juga faktor kemotaktik terhadap neutrofil untuk membantu fagositosis (Skinner, 2009).
Titer antibodi ikan gurami dengan perlakuan vaksin bivalen menunjukkan perbedaan yang nyata dibanding dengan kontrol $(P<0,05)$. Rata-rata titer antibodi setiap perlakuan terjadi peningkatan pada minggu ke2 pascavaksinasi, beberapa perlakuan puncak titer tertinggi diperoleh pada masa minggu ke-3 dan pada saat dilakukan uji tantang terlihat bahwa titer antibodi mengalami peningkatan yang kemudian diikuti adanya penurunan kembali pada masa pemulihan yaitu dua minggu setelah uji tantang (Gambar 1). Hasil titer antibodi yang terbentuk tersebut menunjukkan suatu pola, di mana untuk membentuk level proteksi ikan gurami memerlukan waktu induksi minimal satu minggu (fase adaptasi), terjadi peningkatan pada minggu ke-2 dan ke-3 (fase pertumbuhan), stabil pada 


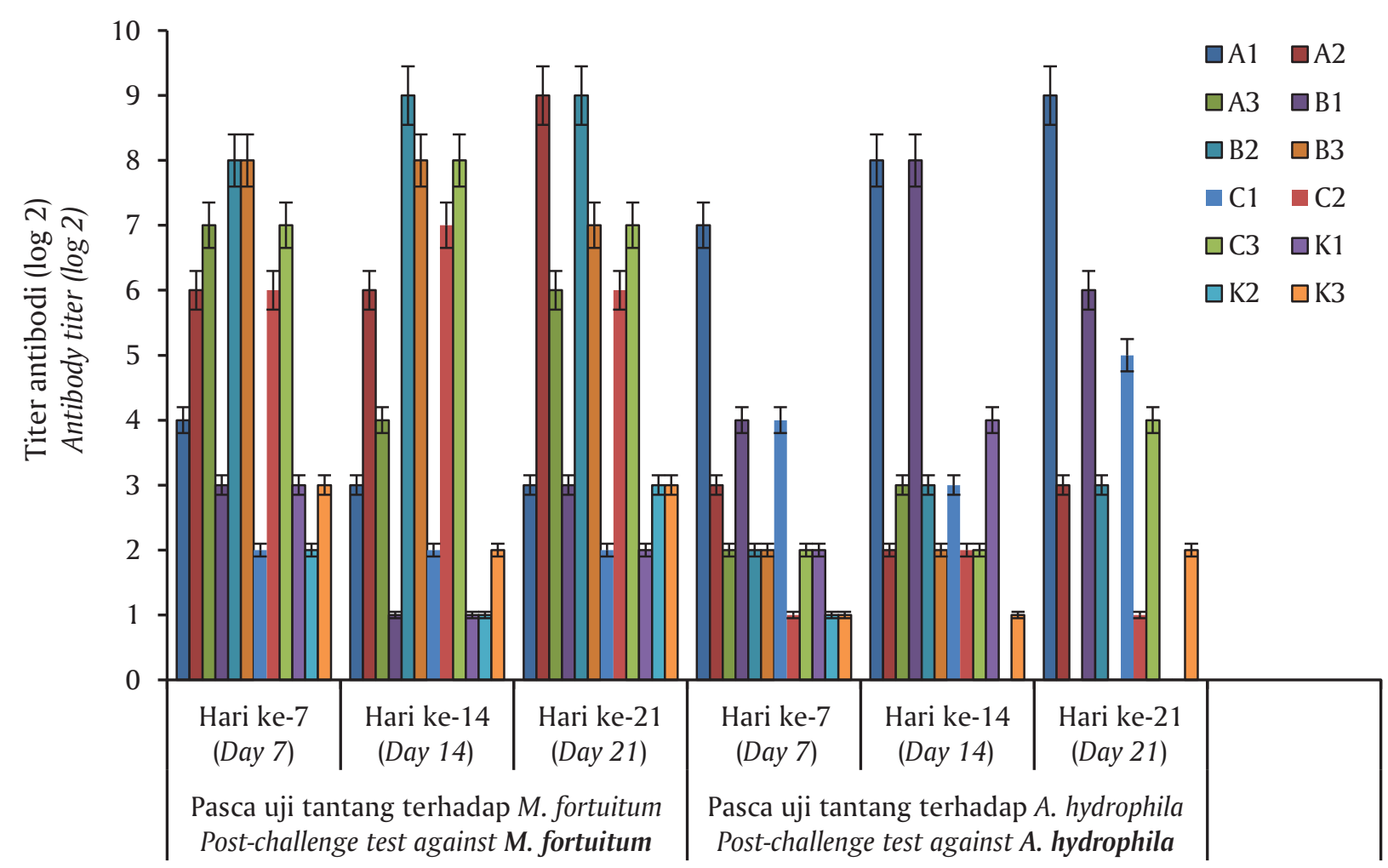

Gambar 1. Pola titer antibodi ikan gurami yang divaksinasi bivalen A. hydrophila dan M. fortuitum melalui injeksi. $\mathrm{A}=$ A. hydrophila $10^{10} \mathrm{cfu}$ dan $M$. fortuitum $10^{9} \mathrm{cfu}$ rasio $1: 1 \mathrm{v} / \mathrm{v}, \mathrm{B}=$ A. hydrophila $10^{9} \mathrm{cfu}$ dan $M$. fortuitum $10^{8}$ cfu rasio $1: 1 \mathrm{v} / \mathrm{v}, \mathrm{C}=$ A. hydrophila $10^{8} \mathrm{cfu}$ dan $M$. fortuitum $10^{7}$ cfu rasio $1: 1$ $\mathrm{v} / \mathrm{v}, \mathrm{K}=$ kontrol (tidak di vaksin)

Figure 1. Pattern of antibody titer of the vaccinated giant gouramy with bivalent vaccine A. hydrophila and $M$. fortuitum by injection. $A=A$. hydrophila $10^{10} \mathrm{cfu}$ and $\mathrm{M}$. fortuitum $10^{9} \mathrm{cfu}$ ratio $1: 1 \mathrm{v} / \mathrm{v}, B=A$. hydrophila $10^{9} \mathrm{cfu}$ and $M$. fortuitum $10^{8} \mathrm{cfu}$ ratio $1: 1 \mathrm{v} / \mathrm{v}, \mathrm{C}=$ A. hydrophila $10^{8} \mathrm{cfu}$ and $\mathrm{M}$. fortuitum $10^{7}$ cfu ratio $1: 1 \mathrm{v} / \mathrm{v}, \mathrm{C}=$ control (unvaccinated)

masa induksi optimal minggu ke-3 sampai minggu ke4 (fase stasioner), dan menurun setelah minggu ke-4 (fase turun). Vaksinasi dapat menstimulasi sistem imun untuk memproduksi antibodi yang akan membantu dalam perlindungan terhadap antigen. Kemampuan peningkatan respons imun ikan setelah vaksinasi dapat dijadikan acuan keberhasilan peningkatan tanggap kebal.

Titer antibodi mencerminkan kemampuan tubuh ikan terhadap infeksi bakteri melalui respons imun spesifik. Semakin tinggi nilai titer maka diharapkan kemampuan perlindungan terhadap infeksi juga menjadi tinggi. Antibodi yang beredar dalam sirkulasi akan menetralisasi molekul antifagositik dan eksotoksin lainnya yang diproduksi bakteri. Mekanisme netralisasi antibodi terhadap bakteri terjadi melalui dua cara. Pertama, melalui kombinasi antibodi di dekat lokasi biologi aktif infeksi yaitu secara langsung menghambat reaksi toksin dengan sel target. Kedua, melalui kombinasi antibodi yang terletak jauh dari lokasi biologi aktif infeksi yaitu dengan mengubah konformasi alosterik toksin agar tidak dapat bereaksi dengan sel target. Ikatan kompleks bersama antibodi membuat toksin tidak dapat berdifusi sehingga rawan terhadap fagositosis, terutama bila ukuran kompleks membesar karena deposisi komplemen pada permukaan bakteri akan semakin bertambah (Skinner, 2009).

Setelah 21 hari, ikan yang divaksinasi melalui injeksi intraperitoneal menunjukkan nilai tertinggi pada total protein dan immunoglobulin, titer aglutinasi dan aktivitas antimikroba. Konsentrasi lisozim dalam serum lebih tinggi pada ikan yang divaksinasi melalui perendaman dibandingkan ikan yang tidak divaksinasi. Vaksinasi intraperitoneal menghasilkan respons imun tertinggi dan dapat digunakan untuk meningkatkan ketahanan ikan terhadap Motil Aeromonas (Da Silva et al., 2013). Ikan Rainbow trout yang diuji tantang minggu ke-3 pasca vaksinasi pada kelompok ikan kontrol terjadi kematian 76\%, kelompok vaksinasi perendaman satu kali terjadi kematian $37 \%$, divaksinasi perendaman dua kali terjadi kematian $4 \%$, kelompok ikan yang divaksinasi injeksi satu kali menunjukkan kematian $2 \%$, dan ikan yang divaksinasi melalui 
perendaman ditambah booster melalui injeksi tidak menunjukkan angka kematian sama sekali. Level proteksi menurun pada bulan ke-5, dan tidak protektif lagi pada bulan ke-7 (Chettri et al., 2013).

\section{Penggunaan Vaksin Bivalen A. hydrophila dan M. fortuitum Melalui Perendaman}

Metode pemberian vaksin melalui perendaman bertujuan untuk mengekspose permukaan luar tubuh ikan secara langsung terhadap larutan vaksin (perendaman langsung) mengandalkan daya serap terutama oleh insang yang memiliki kemampuan imbibisi (peristiwa penyerapan air oleh permukaan zat-zat yang hidrofilik) (Ellis, 1988).

Setelah pemeliharaan masa induksi vaksin selama 28 hari rata-rata bobot ikan meningkat menjadi 71,4 $\pm 8 \mathrm{~g}$ dengan panjang rata-rata $13,87 \pm 3,5 \mathrm{~cm}$; akan tetapi setelah dilakukan uji tantang selama 28 hari bobot rata-rata ikan mengalami penurunan yaitu menjadi $64,25 \pm 11 \mathrm{~g}$ dengan panjang rata-rata 15,84 $\pm 3 \mathrm{~cm}$.

Kemampuan proteksi ikan gurami terhadap uji tantang dengan ko-infeksi $A$. hydrophila dan $M$. fortuitum setelah divaksinasi bivalen yang diaplikasikan melalui perendaman tidak terlalu bagus, walaupun jika dilihat dari titer antibodi yang terukur cukup tinggi ternyata tidak mampu melindungi ikan dari kematian pascainfeksi (Gambar 2). Hal ini dapat dilihat dari nilai RPS tertinggi yaitu hanya sekitar $37,6 \%$ dari perlakuan vaksinasi bivalen dengan dosis perendaman pengenceran ke- 1 campuran antara bakteri $A$. hydrophila $10^{10} \mathrm{cfu}$ dan M. fortutium $10^{9} \mathrm{cfu}$ (Tabel 2). Hasil tersebut sejalan dengan hasil dari beberapa penelitian terdahulu yang menunjukkan bahwa dengan metode injeksi dosis vaksin yang diberikan ke dalam tubuh ikan dapat masuk dan diserap lebih maksimal jika dibandingkan dengan metode perendaman.

Gudmundsdottir et al. (2009) melakukan penelitian untuk mempelajari tingkat antibodi spesifik pada ikan Cod sebelum dan setelah divaksinasi terhadap Vibrio anguillarum dengan pemberian vaksin melalui perendaman, injeksi, dan kombinasi keduanya. Tanggapan antibodi terhadap antigen $V$. anguillarum dalam kelompok ikan yang divaksinasi melalui perendaman dan injeksi sama-sama menunjukkan respons antibodi yang signifikan lebih tinggi jika dibanding dengan kontrol. Akan tetapi ketika diuji tantang, beberapa kelompok ikan yang divaksin melalui perendaman menunjukkan mortalitas yang tinggi dan tidak berbeda nyata jika dibandingkan dengan kelompok ikan kontrol. Melihat hasil ini, disimpulkan bahwa pengukuran titer antibodi tidak dapat dijadikan satu-satunya cara untuk menilai efektivitas dari vaksin.

Perbedaan rute pemberian vaksin berpengaruh terhadap antibodi yang dihasilkan, hal ini berkaitan dengan dosis antigen yang masuk ke dalam tubuh yang kemudian mencetuskan respons imun. Menurut Caron \& Penn (1992), tempat dan cara masuknya antigen ke dalam tubuh turut menentukan jenis respons yang dihasilkan, dan hal ini bergantung pula pada APC (antigen presenting cells) yang menangkap dan memproses antigen bersangkutan. Berbagai jenis APC memproses

Tabel 2. Efikasi vaksinasi bivalen A. hydrophila dan M. fortuitum melalui perendaman

Table 2. Efficacy of a bivalent vaccine A. hydrophila and M. fortuitum by immersion

\begin{tabular}{|c|c|c|c|c|c|}
\hline $\begin{array}{l}\text { Perlakuan uji tantang ko-infeksi } \\
\text { Challenge test co-infection }\end{array}$ & $\begin{array}{l}\text { Ulangan } \\
\text { Repetition }\end{array}$ & $\begin{array}{l}\text { RPS } \\
(\%)\end{array}$ & $\begin{array}{l}\text { ¿Ikan hidup } \\
\text { Survival fish }\end{array}$ & $\begin{array}{l}\text { ¿Ikan mati } \\
\text { Mortality }\end{array}$ & $\begin{array}{c}\text { Sintasan } \\
\text { Survival rate (\%) }\end{array}$ \\
\hline \multirow{3}{*}{$\begin{array}{l}\text { AH } 10^{10} \mathrm{cfu} \text { dan MF } 10^{9} \text { cfu rasio } 1: 1 \mathrm{v} / \mathrm{v} \\
A H 10^{10} \mathrm{cfu} \text { and } M F 10^{9} \mathrm{cfu} \text { ratio } 1: 1 \mathrm{v} / \mathrm{v}\end{array}$} & 1 & 23.2 & 9 & 16 & 36.00 \\
\hline & 2 & 18.4 & 8 & 17 & 32.00 \\
\hline & 3 & 37.6 & 12 & 13 & 48.00 \\
\hline \multirow{3}{*}{$\begin{array}{l}\text { AH } 10^{9} \mathrm{cfu} \text { dan MF } 10^{8} \text { cfu rasio } 1: 1 \mathrm{v} / \mathrm{v} \\
\text { AH } 10^{9} \mathrm{cfu} \text { and } M F 10^{8} \text { cfu ratio } 1: 1 \mathrm{v} / \mathrm{v}\end{array}$} & 1 & 13.6 & 7 & 18 & 28.00 \\
\hline & 2 & 28.0 & 10 & 15 & 40.00 \\
\hline & 3 & 18.4 & 8 & 17 & 32.00 \\
\hline \multirow{3}{*}{$\begin{array}{l}\text { AH } 10^{8} \text { cfu dan MF } 10^{7} \text { cfu rasio } 1: 1 \mathrm{v} / \mathrm{v} \\
\text { AH } 10^{8} \text { cfu and MF } 10^{7} \text { cfu ratio } 1: 1 \mathrm{v} / \mathrm{v}\end{array}$} & 1 & 23.2 & 9 & 16 & 36.00 \\
\hline & 2 & 13.6 & 7 & 18 & 28.00 \\
\hline & 3 & 23.2 & 9 & 16 & 36.00 \\
\hline \multirow[t]{3}{*}{ Kontrol (Control) } & 1 & & 5 & 15 & 33.33 \\
\hline & 2 & & 3 & 17 & 20.00 \\
\hline & 3 & & 2 & 18 & 13.33 \\
\hline
\end{tabular}

Keterangan (Remarks): AH : Aeromonas hydrophila, MF : Mycobacterium fortuitum 


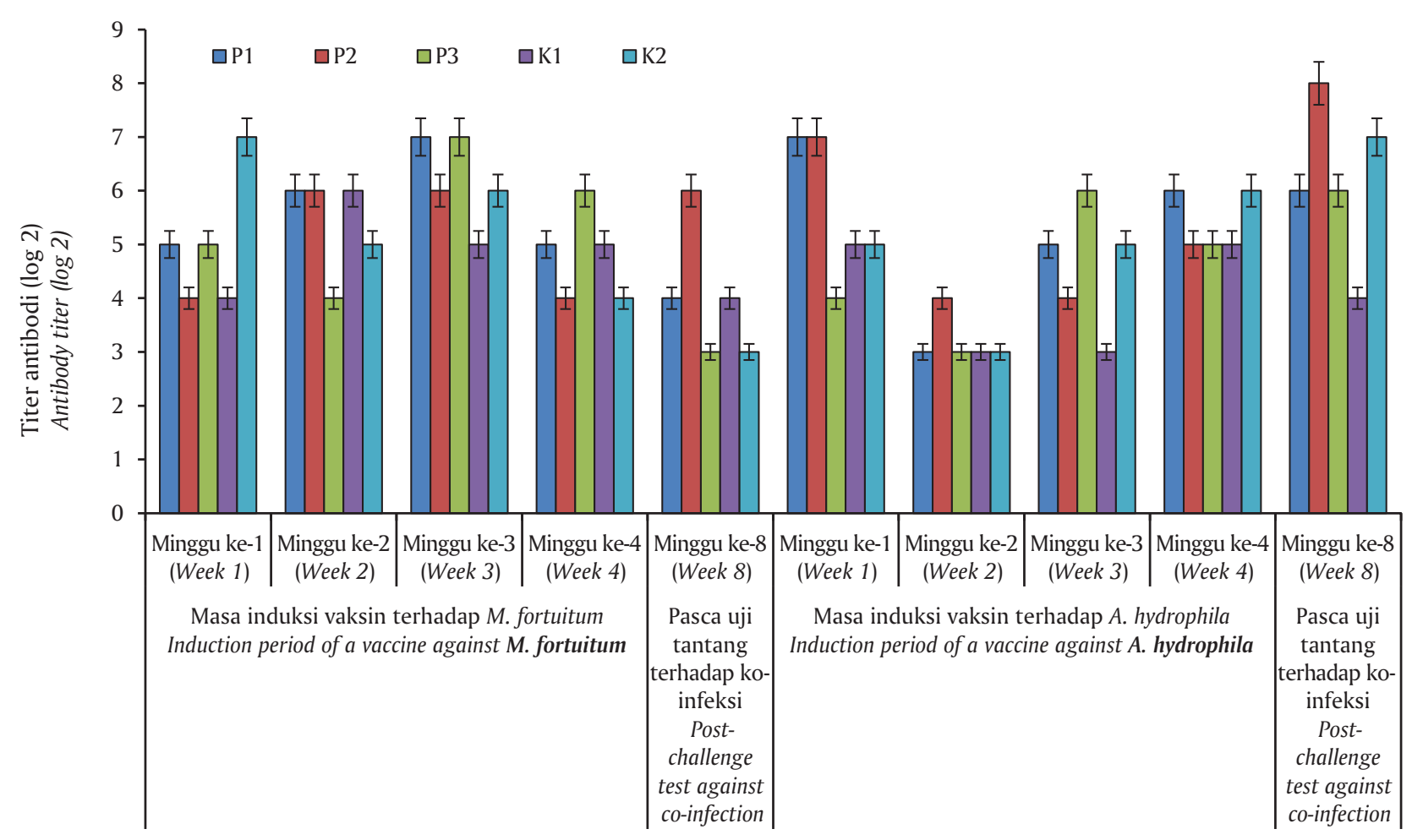

Gambar 2. Pola titer antibodi ikan gurami yang divaksinasi bivalen A. hydrophila dan M. fortuitum melalui perendaman $(\mathrm{P}) . \mathrm{P}=$ A. hydrophila $10^{10} \mathrm{cfu}$ dan $M$. fortuitum $10^{9}$ cfu rasio $1: 1 \mathrm{v} / \mathrm{v}, \mathrm{K}=$ kontrol (tidak divaksin)

Figure 2. Pattern of antibody titer of the vaccinated giant gouramy with bivalent vaccine A. hydrophila and M. fortuitum by immersion (P). $P=A$. hydrophila $10^{10} \mathrm{cfu}$ and $M$. fortuitum $10^{9} \mathrm{cfu}$ ratio $1: 1 \mathrm{v} / \mathrm{v}, \mathrm{C}=$ control (unvaccinated)

antigen dengan cara yang berbeda-beda, misalnya makrofag akan menangkap antigen dengan cara fagositosis dan merombaknya dalam fagolisososom, sedangkan sel dendritik tidak dapat melakukan fagositosis meskipun jenis APC yang potensial. Selain itu, respons imun juga ditentukan oleh sel-sel mana yang diinduksi untuk mengekspresikan molekul MHC dan bagaimana sel itu berinteraksi dengan sel T. Di samping itu, sifat sel APC juga menentukan apakah terjadi respons atau toleransi imunologik. Misalnya bila antigen dipresentasikan oleh sel dendritik atau makrofag teraktivasi yang mengekspresikan MHC kelas II dalam jumlah banyak disertai ekspresi molekul ko-stimulasi, yang terjadi adalah aktivasi sel $\mathrm{T}$ yang sangat efektif. Selain pengolahan dan resentasi antigen seperti yang telah tersebut di atas, maka hal lain yang memengaruhi aktivitas respons imun dalam mengeliminasi antigen adalah rekombinasi gen VDJ yang diatur oleh enzim RAG 1 dan RAG 2, rekombinasi ini akan menentukan sepsefisitas dan aviditas fragmen Fab pada molekul antibodi yang bertugas mengenali epitop antigen (Abbas et al., 2012). Hingga saat ini jenis antibodi pada ikan diketahui hanya IgM, meskipun dilaporkan pada penelitian terbaru yang dilaporkan oleh Zhu et al. (2013) menyatakan bahwa ikan juga menghasilkan antibodi yang mirip dengan IgG seperti IgZ, IgZ-2, IgT, dan chimeric IgM-IgZ yang merefleksikan kompleksitas sistem imun adaptif pada ikan, di samping juga berhasil diidentifikasi beberapa sitokin yang terlibat dalam Th1 dan Th2 dan Treg-like cell.

Vaksinasi melalui perendaman adalah praktek yang umum dalam budidaya, karena kemudahan untuk vaksinasi massal dengan perlindungan yang memadai. Namun, mekanisme penyerapan dan presentasi antigen untuk menghasilkan respons imun yang protektif dan peran sistem kekebalan tubuh bawaannya sebagian besar belum diketahui. Dampak vaksinasi melalui perendaman pada fisiologi ikan, respons imun bawaan dan respons imun spesifik dapat dikarakterisasi dengan bantuan penanda menggunakan partikulat fluorescent dan model antigen terlarut. Seperti yang dilakukan oleh Huising et al. (2003) dengan memvaksinasi ikan mas melalui perendaman langsung (direct immersion/DI) dan perendaman hiper osmotik (hyperosmotic immersion/HI; perendaman langsung namun diawali dengan perendaman singkat dalam 
larutan hipertonik), kedua metode tersebut dapat meningkatkan penyerapan partikel terlarut melalui infiltrasi lewat lapisan epitel dari insang dan kulit. Proses penyerapan ini tidak menyebabkan kerusakan ringan dan tidak menambah stres atas tindakan perlakuan selama penanganan dalam proses vaksinasi melalui perendaman. Metode perendaman hiper osmotik lebih baik dalam mengaktifkan sistem kekebalan tubuh bawaan dari ikan, dan lebih efektif dalam meningkatkan penyerapan vaksin untuk meningkatkan efektivitas di mana komponen vaksin diproses dan disajikan oleh sistem kekebalan tubuh bawaan, serta dapat meningkatkan respons imun mukosa.

\section{Penggunaan Vaksin Bivalen A. hydrophila dan M. fortuitum Melalui Oral (Pakan)}

Vaksin bivalen yang dibuat merupakan vaksin dalam bentuk cair (water based vaccines), maka cara pencampuran dapat menggunakan metode semprot secara langsung pada permukaan pakan (pelet), dengan beberapa catatan bahwa teknik semprotan harus dapat meminimalisir risiko terbentuk aerosol dengan partikel lain, serta penyimpanan pakan yang mengandung vaksin harus pada suhu $2^{\circ} \mathrm{C}-8^{\circ} \mathrm{C}$.

Kemampuan proteksi ikan gurami terhadap uji tantang dengan ko-infeksi $A$. hydrophila dan $M$. fortuitum setelah divaksinasi bivalen yang diaplikasikan melalui pencampuran dengan pakan sangat rendah. RPS tertinggi hanya sekitar $18,4 \%$ dari perlakuan vaksinasi bivalen dengan dosis perendaman pengenceran ke-1 campuran antara bakteri $A$. hydrophila $10^{10} \mathrm{cfu}$ dan M. fortutium $10^{9} \mathrm{cfu}$ dan hasil perlakuan yang lainnya juga terlihat tidak konsisten (Tabel 3), begitu juga dengan titer antibodi yang fluktuatif (Gambar 3) menunjukkan bahwa setiap individu ikan memberikan respons yang berbeda terhadap perlakuan vaksinasi. Hal ini diduga karena adanya kerusakan antigen dari vaksin pada saat melewati saluran pencernaan, dan kesempatan setiap ikan memakan pakan yang mangandung vaksin tidak sama jumlahnya. Terdapat beberapa pendekatan yang dapat diambil dari kasus ini adalah dengan menggunakan bantuan liposom atau alginat untuk melindungi antigen dari tingkat keasaman saluran pencernaan, metode ini lebih dikenal dengan vaksin biofilm (Azad et al., 2000; Ire et al., 2005).

National Office of Animal Health [NOAH] (2006) mengemukakan bahwa obat dalam pakan adalah rute yang paling umum untuk penggunaan melalui oral. Namun, ada beberapa masalah yang terkait dengan rute ini, beberapa anti-bakterial memiliki masalah peletabilitas, adanya pola persaingan ikan berukuran besar dan lebih kuat akan memangsa lebih banyak pakan yang mengandung obat, dan nafsu makan setiap ikan berbeda.

Teknologi vaksin oral telah dikembangkan selama bertahun-tahun sebagai salah satu metode ideal pemberian vaksin untuk ikan. Beberapa faktor yang mulai diteliti adalah presentasi vaksin dalam bentuk yang sesuai, memastikan pemerataan bentuk sediaan untuk seluruh populasi ikan yang akan divaksinasi,

Tabel 3. Efikasi vaksinasi bivalen A. hydrophila dan M. fortuitum melalui oral

Table 3. Efficacy of a bivalent vaccine A. hydrophila and $M$. fortuitum by oral

\begin{tabular}{|c|c|c|c|c|c|}
\hline $\begin{array}{l}\text { Perlakuan uji tantang ko-infeksi } \\
\text { Challenge test co-infection }\end{array}$ & $\begin{array}{l}\text { Ulangan } \\
\text { Repetition }\end{array}$ & $\begin{array}{c}\text { RPS } \\
(\%)\end{array}$ & $\begin{array}{l}\text { SIkan hidup } \\
\text { Survival fish }\end{array}$ & $\begin{array}{l}\sum \text { Ikan mati } \\
\text { Mortality }\end{array}$ & $\begin{array}{c}\text { Sintasan } \\
\text { Survival rate (\%) }\end{array}$ \\
\hline \multirow{3}{*}{$\begin{array}{l}\text { AH } 10^{10} \text { cfu dan MF } 10^{9} \text { cfu rasio } 1: 1 \mathrm{v} / \mathrm{v} \\
\text { AH } 10^{10} \mathrm{cfu} \text { and } M F 10^{9} \mathrm{cfu} \text { ratio } 1: 1 \mathrm{v} / \mathrm{v}\end{array}$} & 1 & 18.4 & 8 & 17 & 32 \\
\hline & 2 & 8.8 & 6 & 19 & 24 \\
\hline & 3 & 13.6 & 7 & 18 & 28 \\
\hline \multirow{3}{*}{$\begin{array}{l}\text { AH } 10^{9} \text { cfu dan MF } 10^{8} \text { cfu rasio } 1: 1 \mathrm{v} / \mathrm{v} \\
\text { AH } 10^{9} \text { cfu and } M F 10^{8} \text { cfu ratio } 1: 1 \mathrm{v} / \mathrm{v}\end{array}$} & 1 & 8.8 & 6 & 19 & 24 \\
\hline & 2 & 0 & 0 & 25 & 0 \\
\hline & 3 & 8.8 & 6 & 19 & 24 \\
\hline \multirow{3}{*}{$\begin{array}{l}\text { AH } 10^{8} \text { cfu dan MF } 10^{7} \text { cfu rasio } 1: 1 \mathrm{v} / \mathrm{v} \\
\text { AH } 10^{8} \text { cfu and } M F 10^{7} \text { cfu ratio } 1: 1 \mathrm{v} / \mathrm{v}\end{array}$} & 1 & 8.8 & 6 & 19 & 24 \\
\hline & 2 & 8.8 & 6 & 19 & 24 \\
\hline & 3 & 18.4 & 8 & 17 & 32 \\
\hline \multirow{3}{*}{$\begin{array}{l}\text { Kontrol } \\
\text { Control }\end{array}$} & 1 & & 5 & 15 & 33.33 \\
\hline & 2 & & 3 & 17 & 20 \\
\hline & 3 & & 2 & 18 & 13.3 \\
\hline
\end{tabular}

Keterangan (Remarks): AH : Aeromonas hydrophila, MF : Mycobacterium fortuitum 


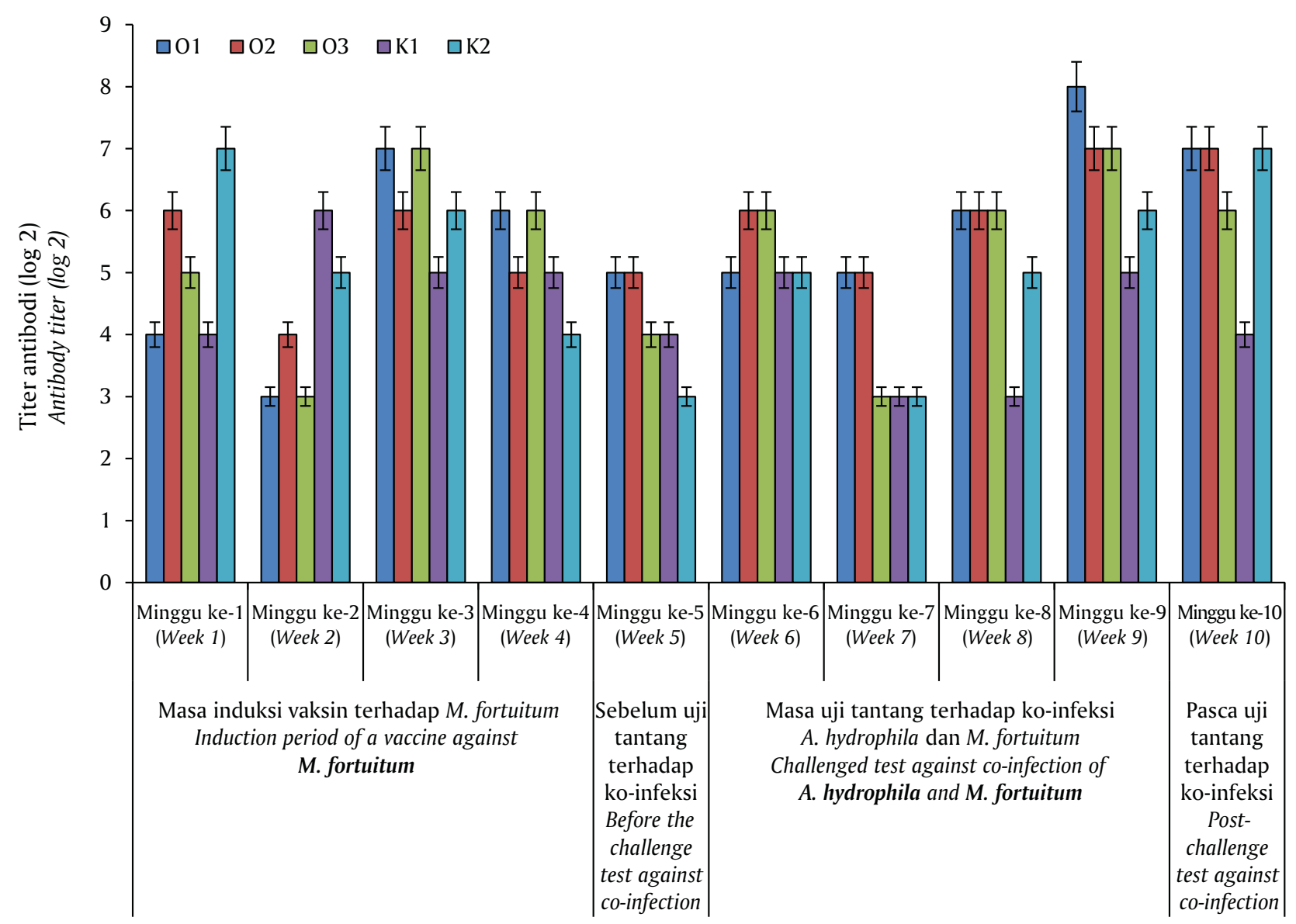

Gambar 3. Pola titer antibodi ikan gurami yang divaksinasi bivalen A. hydrophila dan M. fortuitum melalui oral (O). $\mathrm{O}=$ A. hydrophila $10^{10} \mathrm{cfu}$ dan $M$. fortuitum $10^{9}$ cfu rasio $1: 1 \mathrm{v} / \mathrm{v}, \mathrm{K}=$ kontrol (tidak divaksin)

Figure 3. Pattern of antibody titer of the vaccinated giant gouramy with bivalent vaccine A. hydrophila and M. fortuitum by oral (O). $O=A$. hydrophila $10^{10} \mathrm{cfu}$ and $\mathrm{M}$. fortuitum $10^{9} \mathrm{cfu}$ ratio $1: 1 \mathrm{v} / \mathrm{v}, \mathrm{K}=$ control (unvaccinated)

durasi imunitas, dan penyajian kisaran yang tepat dari antigen. Saluran usus ikan bagian depan sangat asam, hal ini dapat menjadikan masalah dipresentasi antigen dalam vaksinasi oral (Hart et al., 1989). Vaksin harus dilindungi dengan beberapa cara untuk memastikan perjalanan vaksin agar sampai ke usus besar (hindgut) di mana antigen yang memiliki sifat imunopropilaksis dapat diproses oleh sel-sel kekebalan tubuh, teknologi enkapsulasi, akan menjadi tantangan tersendiri dalam penggunaannya.

Durasi kekebalan adalah masalah lain yang dapat membuat ketidakpastian hasil divaksinasi oral. Belum ada zat pembantu yang dapat digunakan divaksin oral untuk memperpanjang presentasi antigen, padahal kemampuan tanggap kebal hampir sepenuhnya tergantung pada sel-sel memori sehingga kesempatan respons imun yang terbentuk relatif sangat singkat.
Oleh karena itu, vaksinasi melalui oral biasanya disarankan untuk penggunaan vaksinasi booster.

Vaksinasi secara oral dapat menggunakan dengan bantuan media lain sebagai pembawa atau dapat berbentuk vaksin yang terenkapsulasi (Kambalapally et al., 2013). Lin et al. (2007) telah mencoba menggunakan vaksin NNV (Nervous necrosis virus) yang dibuat dari Artemia-terenkapsulasi bakteri Escherichia coli rekombinan yang membawa protein kapsid gen NNV. Artemia yang mengandung NNV VP digunakan untuk memvaksinasi larva ikan kerapu secara oral. Analisis immuno-histokimia menunjukkan tujuh hari setelah vaksinasi antigen terserap di usus besar dan membentuk anti-NNV VP antibodi spesifik pada ikan kerapu. Larva yang divaksinasi menunjukkan tingkat perlindungan relatif sebesar $64,2 \%$ dan $69,5 \%$ setelah ditantang dengan NNV virulen. Disimpulkan bahwa, 
vaksinasi NNV melalui oral efektif bisa mengimunisasi larva kerapu dan metode ini dapat diperluas untuk pengembangan vaksin oral lain dan untuk digunakan dalam spesies ikan lainnya. Metode tersebut juga telah dicoba untuk penggunaan KHV (Koiherpes virus) oleh Nuryati et al. (2013) dan memperoleh hasil bahwa Artemia dapat dijadikan sebagai vektor pembawa vaksin plasmid GP-11 untuk larva ikan Cyprinus carpio.

Salah satu tantangan dasar lainnya dengan vaksinasi oral adalah untuk memastikan bahwa setiap ikan menerima jumlah yang cukup dari antigen. Karena ikan diberi makan dalam kelompok besar, dengan pola-pola perilaku dalam kelompok yang berbeda memiliki pengaruh pada serapan pakan, sangat sulit untuk memastikan bahwa semua ikan target menerima vaksin yang cukup. Juga dari sudut pandang komersial, volume antigen yang dibutuhkan untuk metode ini jauh lebih besar dari yang dibutuhkan untuk vaksinasi injeksi individu, terutama jika vaksin ini ditargetkan pada ikan dengan bobot badan besar seperti induk gurami.

Vaksin polivalen merupakan vaksin kombinasi yang terdiri atas dua atau lebih imunogen terpisah yang disatukan dalam produk tunggal, pemberian vaksin seperti ini memiliki kelebihan dalam hal mengurangi jumlah dan risiko trauma akibat injeksi jika diberikan secara suntik sehingga memudahkan pembudidaya dalam aplikasinya, menghemat waktu dan biaya, serta penyimpanan yang lebih mudah. Akan tetapi jika dilihat dari sisi lain penggunaan vaksin polivalen juga memiliki kekurangan misalnya daya imunogenisitas antigen berkurang, reaktogenisitas, dan kesulitan bila terjadi efek samping (Baratawidjaja \& Rengganis, 2012).

\section{KESIMPULAN}

Dosis vaksin terbaik untuk perlakuan vaksin bivalen pada benih ikan gurami melalui injeksi, perendaman, dan oral adalah campuran antara bakteri A. hydrophila $10^{10} \mathrm{cfu}$ dan $M$. fortuitum $10^{9} \mathrm{cfu}$ dengan perbandingan $1: 1 \mathrm{v} / \mathrm{v}$. Rata-rata tingkat RPS setelah uji tantang dengan ko-infeksi $A$. hydrophila dan $M$. fortuitum untuk penggunaan vaksin bivalen melalui injeksi adalah $56,33 \%$; sedangkan melalui perendaman sebesar $26,4 \%$; dan penggunaan melalui oral menghasilkan rata-rata level proteksi $13,6 \%$.

\section{UCAPAN TERIMA KASIH}

Penelitian telah terlaksana dengan sumber dana dari DIPA BPPBAT Tahu Anggaran 2014, Kementerian Kelautan dan Perikanan. Penulis mengucapkan terima kasih kepada Kepala Balai Penelitian dan Pengembangan Budidaya Air Tawar, Bogor; seluruh Peneliti dan staff lainnya, serta teknisi (Sdr. Setiadi,
Edy Farid, Ahmad Wahyudi, dan Johan Affandi) sehingga penelitian ini terlaksana dengan lancar.

\section{DAFTAR PUSTAKA}

Abbas, A.K., Lichtman, A.H., \& Pillai, S. (2012). Cellular and molecular immunology. Elsevier Saunders.

Azad, I.S., Shankar, K.M., Mohan, C.V., \& Kalita, B. (2000). Uptake and processing of biofilm and freecell vaccines of Aeromonas hydrophila in indian major carps and common carp following oral vaccination-antigen localization by monoclonal antobody. Dis. Aqua. Organ., 43, 103-108.

Baratawidjaja, G.K., \& Rengganis, I. (2012). Imunologi dasar. Ed. 10. Badan Penerbit Fakultas Kedokteran, Universitas Indonesia. Jakarta, $568 \mathrm{hlm}$.

Caron, J., \& Penn, G.M. (1992). Electrophoretic and immnochemical characterization of immunoglobulins. In Rose, N.R., deMacario, E.C., Fahey, J.L., Friedman, H., \& Penn, G.M. (Eds.). Manual of clinical labolatory immunology, $4^{\text {th }}$ ed. Washington D.C., Am. Soc. Microbiol., p. 84-95.

Chettri, J.K., Deshmukh, S., Holten-Andersen, L., Jafaar, R.M., Dalsgaard, I., \& Buchmann, K. (2013). Comparative evaluation of administration methods for a vaccine protecting rainbow trout against Yersinia ruckeri 01 biotype 2 infections. Vet. Immunol. Immunopathol. 15, 154(1-2), 42-7. Retrieved November 28, 2014, from http:// www.ncbi.nlm.nih.gov/

Da Silva, B.C., Jatoba, A., Vieira, F.N., Mourino, J.L.P., Bolívar, N., Walter Quadros Seiffert, W.Q., \& Martins, M.L. (2013). Immunization of hybrid surubim (Pseudoplatystoma corruscans x P. fasciatum) against Motile Aeromonas hydrophila septicemia. Braz. arch. biol. technol. 56(1). Retrieved November 28, 2014, from http://www.scielo.br/scielo.php

Ellis, A.E. (1988). General principles of fish vaccination. In Ellis, A-E (Ed.). Fish vaccination. Academic Press. London, p. 1-19.

Evensen, O. (2009). Development in fish vaccinology with focus on delivery methodologies, adjuvants, and formulations. In Rogers, C. \& Basurco, B. (Ed.). The use of veterinary drugs and vaccines in Mediterranean aquaculture. Zaragoza: CIHEAM, 2009. p. 177-186 (Options Méditerranéennes: Série A. Séminaires Méditerranéens: n. 86).

Gudmundsdottir, S., Magnadottir, B., Bjornsdottir, B., Madottir H.A., \& Gudmundsdotti, B.K. (2009). Specific and natural antibody response of cod juveniles vaccinated against Vibrio anguillarum. Fish Shellfish Immunology, 26, 619-624.

Hart, S., Wrathmell, A.B., Harris, J.E., \& Grays, T.H. (1989). Gut immunology in fish: a review. Dev. Comp. Immunpl., 13, 93-100. 
Huising, M.O., Guichelaar, T., Hoek, C., Kemenade, B.M.L.V., Flik, G., Savelkoul, H.F.J., \& Rombout, J.H.W.M. (2003). Increased efficacy of immersion vaccination in fish with hyperosmotic pretreatment. Vaccine, 21, 4178-4193.

Ire, T., Watarai, S., Iwasaki, T., \& Kodama, H. (2005). Protection againts experimental Aeromonas salmonicida infection in carp by oral immunisation with bacterial antigen entrapped in liposomes. Fish Shellfish Immunology, 18, 235-242.

Kambalapally, S., Harel, M., \& Tobar, J.A. (2013). Oral vaccine delivery proves effective in reducing disesases in Salmon. Global Aquaculture Advocate, Februari 2013. p. 70-71.

Lin, C., Lin, J.H., Chen, M., \& Yang, H. (2007). An oral nervous necrosis virus vaccine that induces protective immunity in larvae of grouper (Epinephelus coioides). Aquaculture, 268, 265-273.

National Office of Animal Health [NOAH]. (2006). Responsible use of vaccines and vaccination in fish production. p. 24. Retrieved November 24, 2014, from www.ruma.org.uk

Nuryati, S., Hadiwibowo, S.S., \& Alimuddin. (2013). The potential of Artemia sp. as a DNA vaccine vector for common carp Cyprinus carpio larvae. Jurnal Akuakultur Indonesia, 12(1), 59-67.

Osman, K.M., Mohamed, L.A., Rahman, E.H.A., \& Soliman, W.S. (2009). Trials for vaccination of Tilapia fish against Aeromonas and Pseudomonas infections using monovalent, bivalent, and polyvalent vaccines. World Journal of Fish and Marine Sciences, 1(4), 297-304.

Purwaningsih, U., Indrawati, A., \& Lusiastuti, A.M. (2014). Proteksi vaksin monovalen dan koktail sel utuh terhadap ko-infeksi Mycobacterium fortuitum dan Aeromonas hydrophila pada ikan gurami, Osphronemus goramy. J. Ris. Akuakultur, 9(2), 283294.

Skinner, L.A. (2009). The Physiological and Immunological effects of vaccination on fish health, welfare, and performance. The University of British Columbia, 139 pp.

Sommerset, I., Krossoy, B., Biering, E., \& Frost, P. (2005). Vaccines for fish in aquaculture. Expert Rev. Vaccines, 4(1), 89-101.

Suanyuk, N., \& Itsaro, A. (2011). Efficacy of inactivated Streptococcus iniae vaccine and protective effect of â-(1,3/1,6)-glucan on the effectiveness of vaccine in red tilapia Oreochromis niloticus x 0 . mossambicus. Songklanakarin Journal Science Technology, 33(2), 143-149.

Sugiani, D., Lusiastuti, A.M., \& Taukhid. (2013). Laporan teknis Pengembangan vaksin bivalen untuk pencegahan penyakit Mycobacteriosis dan Motile Aeromonas Septicemia. Balai Penelitian dan Pengembangan Budidaya Air Tawar, Bogor, Indonesia, $51 \mathrm{hlm}$.

Toranzo, A.E., Romalde, J.L., Magarinos, B., \& Barja, J.L. (2009). Present and future of aquaculture vaccines against fish bacterial diseases. The use of veterinary drugs and vaccines in Mediterranean aquaculture. Options Mediterraneennes, A., 86, 155176.

Zhu, Lv-y., Li, N., Zhu, G., Xiang, L., \& Shao, J.Z. (2013). Advances in research of ûsh immune-relevant genes: A comparative overview of innate and adaptive immunity in teleosts. Developmental and Comparative Immunology, 39, 39-62. 
